\title{
Systematic studies (morphology, anatomy, palynology) of an economically important grass Sporobolus diandrus (Retz.) P. Beauv. (Poaceae)
}

Saurav Dwari* and Amal Kumar Mondal

Plant Taxonomy, Biosystematics and Molecular Taxonomy Laboratory, Department of Botany and Forestry,

Vidyasagar University, Midnapore-721 102, West Bengal, India.

Received: 3/22/2018; Revised: 4/11/2018; Accepted: 4/23/2018

\begin{abstract}
Sporobolus diandrus (Retz.) P. Beauv, a medicinally important agrestal which is also considered as a fodder grass in eastern India. The species commonly used as green foliage; grazing and medicinal plants to local peoples. But the morphological study of this plant was very poor and there was no anatomical and palynological study. The present study deals with few systematic parameters viz. morphology, anatomy, palynology of Sporobolusdiandrus (Retz.) P. Beauv. The result shows some distinct morphological and anatomical as well as palynological characters. These characters are very important for proper and rapid identification.
\end{abstract}

Keywords: Sporobolus diandrus, Morphology, Anatomy, Palynology, Medicinally important, India

\section{Introduction}

Sporobolus diandrus (Retz.) P. Beauv is an agrestal and ruderal weed in India. It has been used in India as a medicinal plant species. This plant can be a very aggressive invader, particularly in low-lying ungrazed areas (Riggins, 1977). It is often found in wet situations, especially in some fields' areas (Bor, 1960). Sporobolus diandrus (Retz.) P. Beauv. is under the subfamily Chloridoideae of family Poaceae (Simon, 1999). Poaceae, also known as Gramineae is the one of the largest family of the world. In India this family has 263 genera and 1291 species. It is the largest family of the India (Jain, 1986). Among those Sporobolus diandrus (Retz.) P. Beauv. very common in West Bengal as well as in India. They also useful for banks of steams to control erosion (Karthikeyon and Kumar, 1983). Morphological, Anatomical (Esau, 1965), Palynological characters are very important to characterize and classify any plant properly. These characters are also required for database preparation in this digital world. By which further experiments or research will be done. These characters are very important for proper and rapid identification. But detail morphological, anatomical, palynological studies of Sporobolus diandrus (Retz.) P. Beauv. as well as other grasses are very less. Morphological, anatomical and pollen characters now apply in solving of controversial taxonomical and phylogenetical problems (Balasbramanian et al., 1993). Major morphological characters are hair structure, stomatal structure, flowers structure etc. Major anatomical characters are cortex, vascular bundle characters etc. Characters of pollen grain are apertural form, number, distribution and position etc (Dwari and Mondal, 2011).

*Corresponding Author:

Saurav Dwari,

Plant Taxonomy,

Biosystematics and Molecular Taxonomy Laboratory,

Department of Botany and Forestry,

Vidyasagar University, Midnapore-721 102, West Bengal, India.

E-mail: saurav.dwari@gmail.com

\section{Materials and Methods}

Plant specimen was collected from agricultural fields of Gangetic region (surrounding of the river Ganga) of West Bengal which is situated in the eastern part of India. Then prepared a herbarium specimen of the species. Next plant is identified from Central National Herbarium $(\mathrm{CNH})$ of Botanical Survey of India (BSI) memo no. CNH/59/2011Tech. II/619 dated 29.12.2011. Then plant specimen deposited in herbaria of Vidyasagar University. Plant sample washed in deionized water and some plants fixed in the alcohol for anatomical studies. Twigs, roots, stems, leaves, flowers, seeds and pollens were collected time to time during visit. Flowering twigs are collected for morphological study. Pollens were collected for pollen study. Morphological parameters which have taxonomic value (length of vegetative and floral parts, type of stamen, carpel were determined. Anatomical study done by simple transverse section of root, stems (culms) and leaves (Johanson, 1940). To study of stomata the paradermal cross sections were taken (Algan, 1981).

\section{Results}

Morphological description

Sporobolusdiandrus (Retz.) P. Beauv. is an erect, perennial; not rhizomatous plant (Figure 1A and 2A). Culms are $160-300 \mathrm{~cm}$. in height, greenish, cylindrical, node and internodes prominent, internodes solid, node swollen, glabrous, and soft. Sheath is mostly longer than internodes, papillose, pubescent. Hairs are about $0.45-1 \mathrm{~mm}$ long. They are unicellular and cylindrical type (Figure 3A). Leaves (blades) Simple, 20-50 cm long, linear, narrow, 
folded, rolled, apex acuminate, pubescent, venation parallel, pubescent. Inflorescence Panicle (racemes), $10-30 \mathrm{~cm}$ long, axes ending in spikelets, rachis hollow, and spikelet bearing axes persistent, pedicelate. Spikelets solitary and $1.3-3 \mathrm{~cm}$ long (Figure 2B). Rachilla prolonged, first glume acute, about $1 \mathrm{~mm}$ long, not clasping at base, second glume and lemma equal, acute, they latter subtending a hyaline palea, fertile lemma slightly shorter, membranous, shiny, lodicules 2, free, glabrous (Table 1) (Figure 1B, C, D, E and 2C, D, E, F). Stamens 23 , free, exerted, filaments short, anthers bi-celled, versatile, dehiscing longitudinally (Figure $1 G$ and $2 \mathrm{G})$. Gynoecium monocarpellary, ovary superior, unilocular, single ovule, placentation basal, style two, medium, stigma feathery (Figure $1 \mathrm{H}$ nd $2 \mathrm{H}$ ). Fruit is small and Caryopsis type (Figure 3B).

\section{Anatomical description}

Root: Epidermis is uniseriate composed of closely set, thin walled tabular cells without cuticle, unicellular root hair present. Cortex is exodermis is present, occurring after one parenchymatous layer as multiseriate layer and composed of lathery thickwalled cells. The rest portion of cortex i.e. internal cortex is composed of loosely thin walled cells having intercellular spaces. Endodermis, the innermost layer of the cortex is provided with thick secondary radial and inner walls. Pericycle is outermost uniseriate layer of stele. Vascular bundle is polyarch and radial i.e. phloem strand alternate to xylem strand. Xylem exarh Protophloem lies towards periphery and metaphloem lies towards the centre. Pith is large, central in position and surrounded by a circle of metaxylem vessels. It is composed of loosely arranged parenchymatous cells (Figure 3C).

Table 1. Morphological measurements of Sporobolus diandrus (Retz.) P. Beauv.

\begin{tabular}{clc}
\hline $\begin{array}{c}\text { No. of } \\
\text { characters }\end{array}$ & \multicolumn{1}{c}{ Organs } & $\begin{array}{c}\text { Measurements of } \\
\text { length }\end{array}$ \\
\hline 1 & Stem & $160-300 \mathrm{~cm}$ \\
2 & Hair & $0.45-1 \mathrm{~mm}$ \\
3 & Leaves & $20-50 \mathrm{~cm}$ \\
4 & Spikelet & $1.3-3 \mathrm{~cm}$ \\
5 & First Glume & $1.5-1.7 \mathrm{~mm}$ \\
6 & Second Glume & $1.2-1.4 \mathrm{~mm}$ \\
7 & Third & $0.85-1 \mathrm{~mm}$ \\
& Glume(Lemma) & $1.2-1.5 \mathrm{~mm}$ \\
8 & Fourth & $0.5 \mathrm{~mm}$ \\
\hline
\end{tabular}

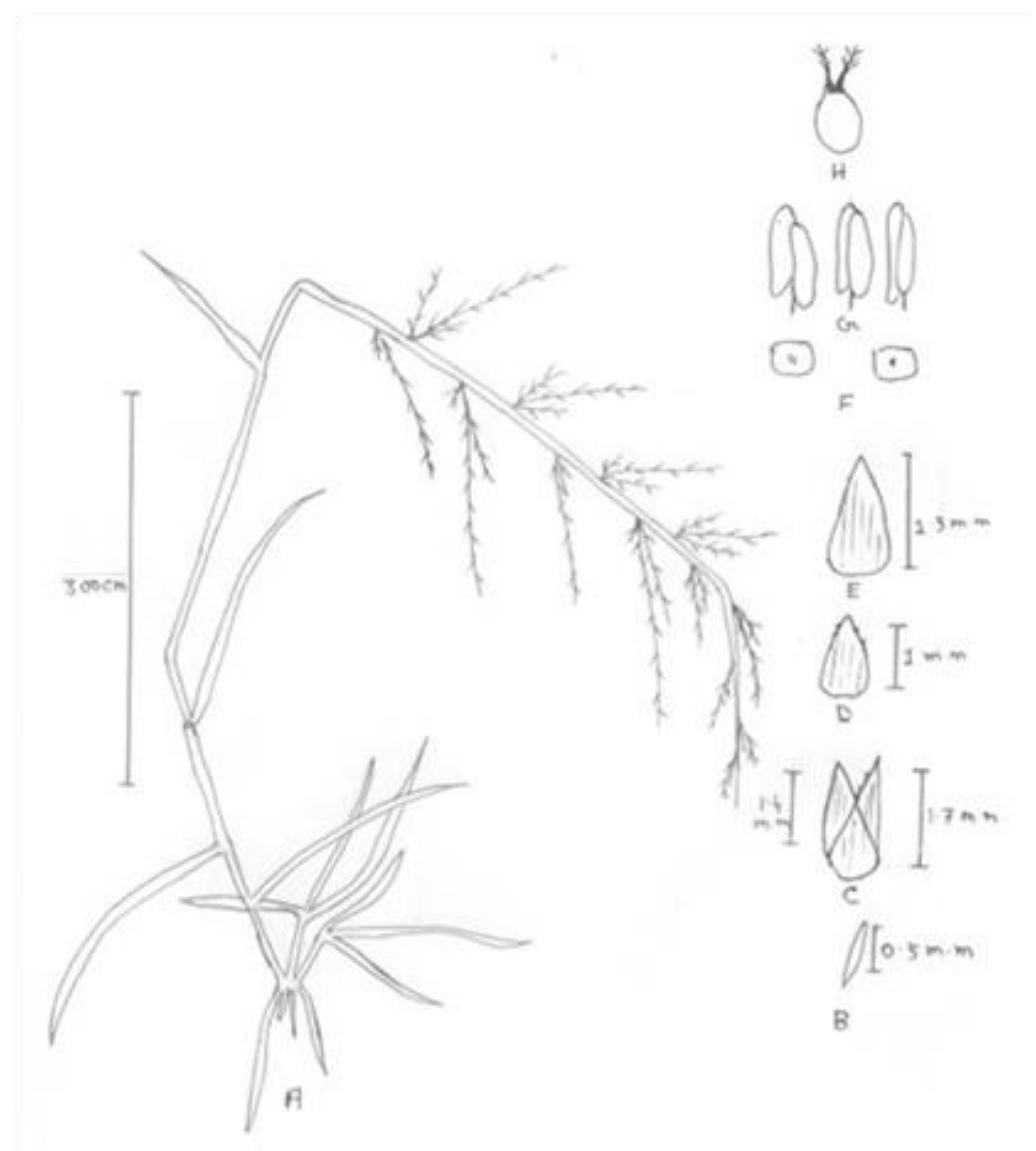

Figure 1. A) Flowering twig. B, C, D, E) Glumes. F) Lodicules. G) Stamens. H) Carpel. 


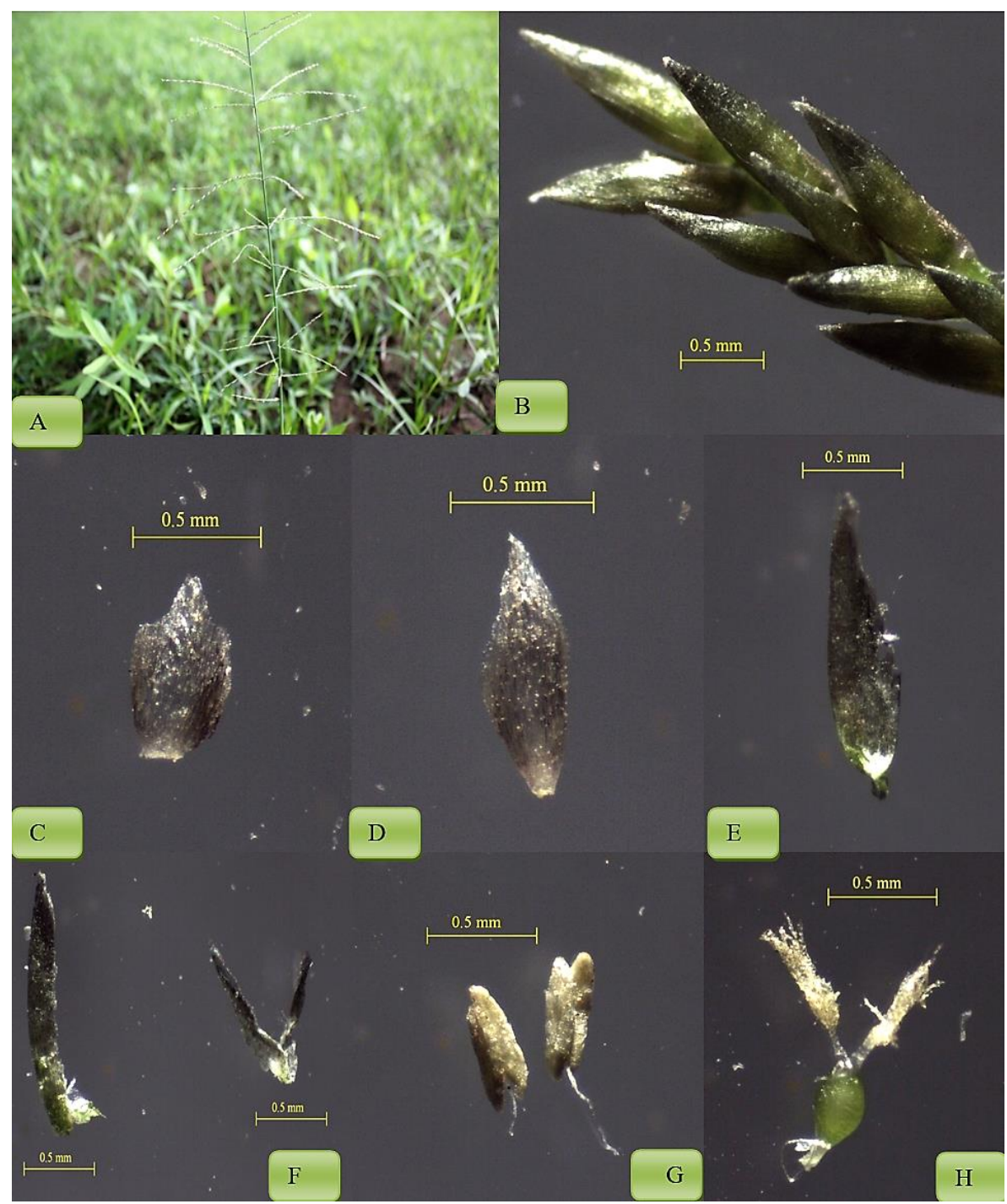

Figure 2: Digital and Microscopic Photographs. A) Flowering twig. B) Inflorescence. C, D, E, F) Glumes. G) Stamens. H) Carpel.

Stem (Culm): Epidermis is outermost single layered, composed of closely fitted tabular cells. Cuticle absent in outer wall. Epidermal cells are too small. True cortex is absent. Not differentiated into extrastelar and intrastelar regions. Next to the epidermis there occur several layers of thick walled sclerenchymatous cells. Then several cell-layer parenchymatous cells are present. To the centre cells are become larger. Vascular bundle is closed and collateral. Arranged in two rings-the outer ring of smaller vascular bundles are associated with subepidermal continuous sclerenchymatous band and the second ring of larger bundles is placed lower in the parenchymatous ground tissue. Vascular bundles are surrounded by sclerenchyma sheath called bundle sheath. Xylem occurs in the form of later "Y"-two metaxylem with larger cavities situated laterally i.e. at the two arms of the later "Y and two protoxylem vessels with smaller cavities in mature bundle lowermost protoxylem undergoes dissolution forming a cavity known as protoxylem lacuna. Xylem endarch. Phloem is above the two metaxylem vessels.
Pith and medullary rays are not differentiated due to the scattered arrangement of bundles over the ground tissue (Figures 3D and 3E).

Leaf: There are two epidermal layers viz-an upper and a lower epidermis. Both the epidermal layers are composed of compactly arranged, almost oval or rectangular thin walled cells and posses distinctly cuticle. Stomata present on both epidermis (Figure $3 \mathrm{~F}$ and $3 \mathrm{G})$. Upper epidermis with distinct ridge and furrow. Sclerenchyma occurs in the form of patches below the upper epidermis and next to the lower epidermis. Mesophyll tissueis not differentiated. Composed of only spongy type of isodiametric cells. Vascular bundles are different sizes. The bundle is collateral and closed, phloem lies towards the lower epidermis and xylem towards the upper side. Each Vascular bundle surrounded by bundle sheaths. The larger bundles are associated with the subepidermalfibre plated or sclerenchyma plate (known as bundle sheath extension) next to epidermal layers (Figure 3F and $3 \mathrm{G}$ ). 


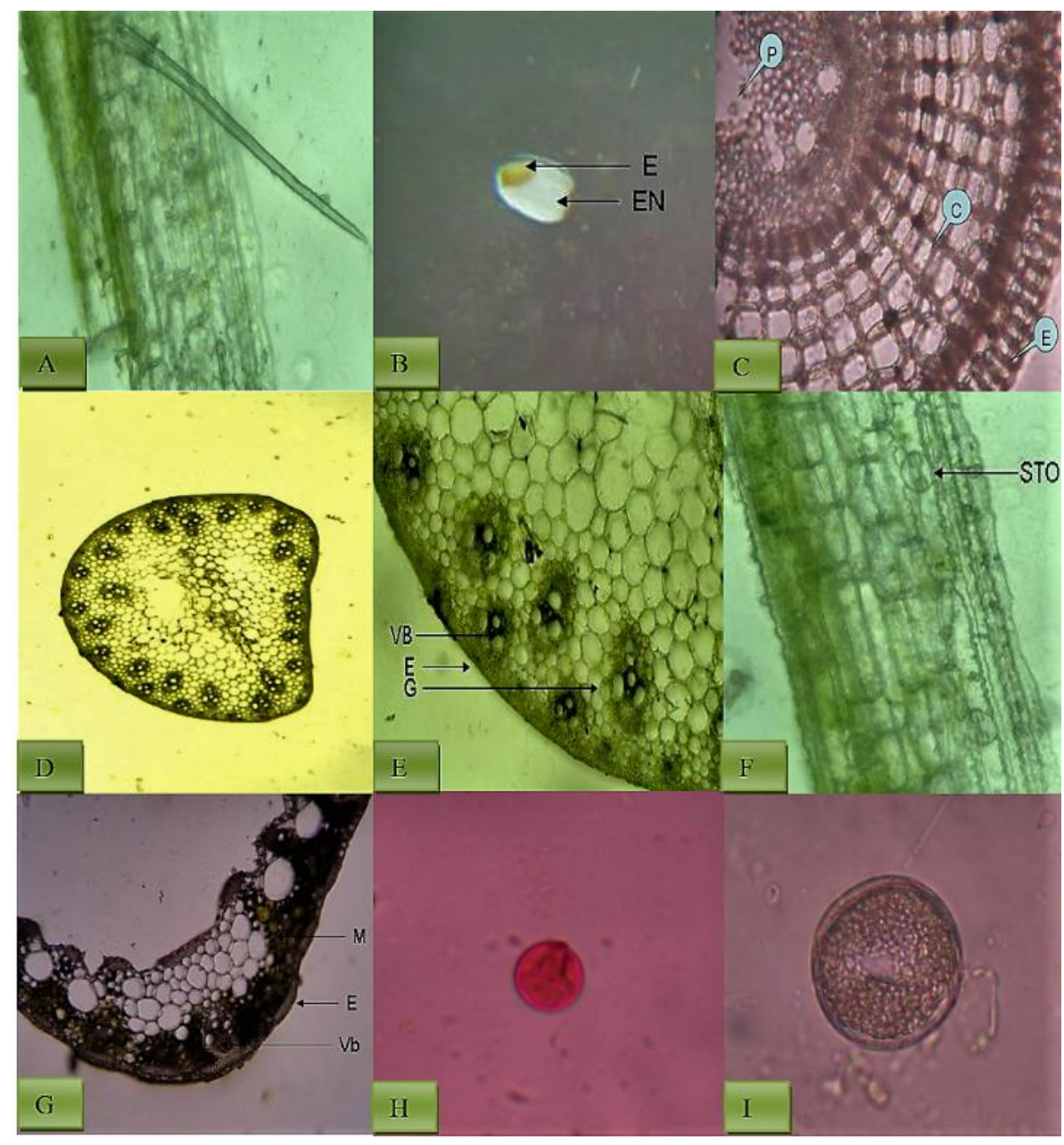

Figure 3: A) Unicellular cylindrical hair of leaf sheath. B) Seed. C) T.S of root (E. Epidermis, C. Cortex, P. Pith). D) T.S of stem. E) Close up view of T.S of stem (Culm). (E. Epidermis, VB. Vascular bundle G. Ground tissue). F) Leaf epidermis [Sto. Stomata (paracytic type)] (Culm). G) T.S of leaf (E. Epidermis, M. Mesophyll tissue, VB. Vascular bundle. H) Pollen. I) Pollen after staining.

\section{Palynological description}

Pollen grains of Sporobolusdiandrus are Circular in polar view, prolate-spheroidal in equatorial view. Generally, these are small in size and monad type. Diameter is about $18 \mu \mathrm{m}$ (Table 2). Apertural form of pollens is monocolpate type and position is proximal. Exine is thicker than intine. Exine surface is smooth (Figure $3 \mathrm{H}$ and $3 \mathrm{I}$ ).

Table 2. Important palynological characters of Sporobolus diandrus (Retz.) P. Beauv.

\begin{tabular}{|c|c|c|}
\hline $\begin{array}{c}\text { No. of } \\
\text { characters } \\
\text { observed }\end{array}$ & Character & Sporobolus \\
\hline 1 & Shape of the pollen & $\begin{array}{l}\text { Circular, prolate } \\
\text { spheroidal. }\end{array}$ \\
\hline 2 & Number of apertures & Monoaperturate \\
\hline 3 & Morphology & $\begin{array}{l}\text { Ectexine more or less } \\
\text { smooth. }\end{array}$ \\
\hline 4 & Pollen size & $18 \mu \mathrm{m} \pm$ \\
\hline 5 & Pollen association & Monad type \\
\hline
\end{tabular}

\section{Discussion}

Some morphological characters of Sporobolusdiandrus (Retz.) P. Beauv. are very attractive. We can use these characters for identification purpose. Morphologically this plantisa creeper, stoloniferous, with solid internodes and swollen nodes. Long pubescent sheath is present. Leaves are simple with acute apex and scabrous margin. Glumes with obtuse apex and relatively short inflorescence. Stamens with broad anther and short filament. Carpel with long style and reddish stigma. Anatomically it has single layer root epidermis with thick cuticle. Exodermis is of present just beneath the epidermis. Vascular bundle is polyarch and radial with exarch xylem. In stem chlorenchymatous layer is present just beneath the stem epidermis. Vascular bundles are scattered in ground tissue with endarh xylem. Leaves with abundant paracytic type of stomata. Important palynological characters are small, oblate spheroidal, monad type, monocolpate pollen with columnar ectexine and retipliateexine which are also can use in identification purpose.

\section{Conclusion}

All these characters are too much helpful to know the taxonomical characteristic of the taxa for proper 
identification, systematical analysis, future experimental research and Phylogenetic interrelationship among the Sporobolus genus. Plant is medicinally very important to local peoples. The plant is used to enrich the blood, reduce swellings and correct gonorrhea. The fruit decoction is used to bathe wounds and heal sores in the mouth. Syrup prepared from the fruit is taken to overcome chronic diarrhea. The astringent bark decoction is a remedy for mange, ulcers, dysentery and for bloating caused by intestinal gas in infants. So, these identifying characters are will be very useful to rapid and proper identification of this important plant species.

\section{Acknowledgement}

Authors would like to express heartfelt indebtedness to Dr. Proshanta Bhatyachrjee and BSI for identification and providing the other technical support. We would also want to convey our gratitude to the honorable Dr. Sanjukta Mondal (Parui), WBES, HOD, Co-ordinator DST-BOOST-WB and Associate Professor, Post Graduate Department of Zoology, Lady Brabourne College, Kolkata-700017, West Bengal, India, for her consistence help during our study period. Also like to express our gratitude to UGC for their laboratory support in the form of DRS-SAP (Phage II) [2011-2016]. Special thanks to Sanjit Sinha for his support to our study. Authors would like to express thanks to all research scholars of Plant Taxonomy, Biosystematics and Molecular Taxonomy laboratory. I am also thankful to my parents and family to support me.

\section{References}

1. Algan, G. "Microtechnique for plant tissues". University of Firat publications, Istanbul, 1 (1981): 194. Printed.

2. Balasbramanian, A. J., Thresiamma, J., Saravanan, S. and Jacob, T. "Petiolar anatomy as an aid to the identification of Cinnamomum species (Lauraceae)". Indian Forester. 119 (1993):583-586. Online.

3. Bor, N.L. "The Grasses of Burma, Ceylon, India \& Pakistan”. Pergamen Press. London. (1960). Printed.

4. Dwari, S. and Mondal, A.K. "Systematic studies (Morphology, anatomy and palynology) of economically viable grass Bracbiariamutica (Forskil) Staph in eastern India". Afr. J. Plant Sci. 5(5) (2011): 296-304. Online.

5. Esau, K. Anatomy of seed plants. John Wiley and Sons, New York. (1965). Printed.

6. Jain, S.K. "The Grass Flora of India. A Synoptic account of uses and Phytogeography". Bul. Bot. Surv. India. 28(1-4) (1986):229-240. Online.

7. Johanson, D.A. Plant microtechnique, Mc. Grow Hill, New York. 1940. Printed.

8. Karthikeyon, S. and Kumar, S. "New and Interesting Plant Records from Maharastra". J. Bombay Nat. Hist. Soc., 80 (1983): 254-258. Printed.

9. Simon, B.K. and Jacobs, S.W. L. "Revision of the genus Sporobolus (Poaceae, Chloridoideae) in Australia”. Aust. Syst. Bot. 12 (1999): 375-448. Online.

10. Riggins, R. "A Biosystematic study of the Sporobolus asper complex (Gramineae)". Iowa State", J. Res. 51 (3) (1977): 287-321. Online.

\section{Cite this article as:}

Saurav Dwari and Amal Kumar Mondal. Systematic studies (morphology, anatomy, palynology) of an economically important grass Sporobolus diandrus (Retz.) P. Beauv. (Poaceae). Annals of Plant Sciences 7.5 (2018) pp. 2226-2230.

do $\mathrm{http://dx.doi.org/10.21746/aps.2018.7.5.4}$ 